ASSESSMENT OF ACADEMIC TRAINING AND JOB PLACEMENT IN GRADUATES FROM TEACHING IN BASIC EDUCATION PROGRAMS IN CHILE ${ }^{1}$

\author{
OSCAR ESPINOZA ${ }^{1 *}$ \\ ORCID: https://orcid.org/0000-0001-7525-2980 \\ LUIS GONZÁLEZ2** \\ ORCID: https://orcid.org/0000-0003-1850-3899 \\ LUIS SANDOVAL ${ }^{3 * * *}$ \\ ORCID: https://orcid.org/0000-0002-8988-7888 \\ DANTE CASTILLO4 **** \\ ORCID: https://orcid.org/0000-0002-5648-0627
}

\begin{abstract}
The expansion of access to higher education represented an advancement for the integration of traditionally excluded groups in Chile. However, expanding access is insufficient to ensure the equity of the higher education system. Under this premise, the article seeks to investigate aspects of academic training and employment from the perception of graduates, considering that these dimensions reflect relevant aspects of the degree of equity that could be evidencing the Chilean system. This exploratory study focused on graduates of the Teaching for Basic Education career of three universities with different levels of selectivity of their students. We conclude that there is no evidence that the degree of selectivity, as well as
\end{abstract}

\footnotetext{
${ }^{1}$ Universidad de Playa Ancha, Centro de Estudios Avanzados, Viña del Mar, Chile.

“Doctor en Política, Planificación y Evaluación en Educación. Investigador en el Centro de Estudios Avanzados de la Universidad de Playa Ancha e investigador en el Programa Interdisciplinario de Investigaciones en Educación (PIIE). E-mail:< oespinoza@academia.cl>.

${ }^{2}$ Programa Interdisciplinario de Investigaciones en Educación (PIIE), Santiago, Chile.

“" Doctor en Administración y Planificación Educativa. Investigador en el Programa Interdisciplinario de Investigaciones en Educación (PIIE). E-mail: < legonzalez.fiegehen@gmail.com>.

${ }^{3}$ Universidad Tecnológica Metropolitana, Santiago, Región Metropolitana, Chile.

"** Magister en Ciencia Política. Director de Docencia, Universidad Tecnológica Metropolitana. E-mail: $<\mid$ sandoval@utem.cl $>$.

${ }^{4}$ Programa Interdisciplinario de Investigaciones en Educación (PIIE), Santiago, Chile.

**** Sociólogo. Investigador en el Programa Interdisciplinario de Investigaciones en Educación (PIIE). E-mail:<dcastillo@estudiospiie.cl >.
} 
the characteristics and attributes of the academic training received by the graduates of different universities, are perceived as determining factors for the job placement of graduates.

Keywords: Chile; Teaching Programs; Academic training; Employability.

\section{VALORACIÓN DE LA FORMACIÓN ACADÉMICA Y DE LA INSERCIÓN LABORAL EN TITULADOS DE PEDAGOGÍA EN EDUCACIÓN BÁSICA EN CHIL}

RESUMEN: La expansión del acceso a la educación superior universitaria ha representado un avance para la integración de grupos tradicionalmente excluidos en Chile. Sin embargo, la apertura del acceso resulta insuficiente para asegurar la equidad del sistema de educación superior. Bajo esta premisa, el artículo se ocupa de indagar en torno a la formación académica y la inserción laboral desde la percepción de los titulados, considerando que esas dimensiones reflejan aspectos relevantes del grado de equidad que podría estar evidenciando el sistema chileno. Este estudio exploratorio se focalizó en titulados de la carrera de Pedagogía en Educación Básica de tres universidades con distintos niveles de selectividad de sus alumnos. Concluimos que no existe evidencia a favor de que el grado de selectividad, así como las características y atributos de la formación académica recibida por los titulados de distintas universidades, sean percibidos como factores determinantes para la inserción laboral de los titulados.

Palabras clave: Chile; Programas de Pedagogía; Formación académica; Empleabilidad.

\section{AVALIAÇÃO DA FORMAC̣ÃO ACADÊMICA E DA INSERC̣ÃO LABORAL ENTRE GRADUADOS DE PEDAGOGIA EM EDUCAÇÃO BÁSICA NO CHILE}

RESUMO: A expansão do acesso à educação superior universitária representou um avanço para a integração de grupos tradicionalmente excluídos no Chile. No entanto, a expansão do acesso resultou insuficiente para assegurar a equidade do sistema de educação superior. Sob essa premissa, o artigo se ocupa em indagar acerca da formação acadêmica e da inserção laboral de acordo com a percepção dos graduados, considerando que essas dimensões refletem aspectos relevantes do grau de equidade que poderia estar evidenciando o sistema chileno. Este estudo exploratório teve como foco os graduados do curso de Pedagogia em Educação Básica de três universidades com distintos critérios de seleção de seus alunos. Concluímos que não existe evidência a favor de que o grau de seleção e as características e atributos da formação acadêmica recebida pelos graduados de distintas universidades sejam percebidos como fatores determinantes para a inserção laboral dos graduados.

Palavras-chave: Chile; Programas de Pedagogia; Formação Acadêmica; Empregabilidade. 


\section{INTRODUCTION}

As it has been sufficiently verified, at the end of the 1980s, the Chilean higher education system underwent a process of expansion of coverage (BRUNNER, 2009, OECD, 2013, GALLEGUILLOS, HERNÁNDEZ, SEPÚLVEDA, VALDÉS, 2016). Enrollment increased from less than 250,000 students in 1990 to 1,176,727 in 2017. In this last year universities enrolled $56.5 \%$ of the total students enrolled in the system (SIES, 2017).

This expansion was socially segmented (ESPINOZA, 2008; CARRASCO; ZÚÑIGA; ESPINOZA, 2014). The growth of the university system was mainly due to an increase in enrolment by students belonging to the lower income quintiles (1, 2 and 3), who gained access, in most part, to private higher education institutions. These were founded after 1981 and admitted soaring numbers of students. The means to achieve this massive almost unfettered enrolment was an increase in admission and a dramatic drop in selectivity, a development that contrasted to what had taken place before 1981 in Chile's university system (ESPINOZA; GONZÁLEZ, 2007, 2015; BRUNNER; URIBE, 2007; BRUNNER, 2009; LEYTON; VÁSQUEZ; FUENZALIDA, 2012). This has led to a diversification of the structure of the student body (SIES, 2014) which now includes, for example, many ( 7 in 10) who are the first generation in their family to achieve a university education (ESPINOZA; GONZÁLEZ; URIBE, 2009; ACCIÓNEDUCAR, 2015).

Since the 1980 reform of higher education in the country, different government interventions contributed to consolidate this trend, such as the establishment of a system of loans and scholarships, as well as financial support provided to the higher education institutions which enabled them to set up arrangements which fostered the retention of students from low income backgrounds. Indeed, since 1990 the democratic governments sought to increase equity in access to the higher education system by developing several loan and scholarship programs that supplemented those conceived in the previous decade (ESPINOZA, 2013; LATORRE; GONZÁLEZ; ESPINOZA, 2009). In addition, several mechanisms were also set up to prevent dropping out from universities, which represented an answer to the requirements stated by the Natonal Accreditation Commission (COMISIÓN NACIONAL DE ACREDITACIÓN, 2014).

One of the consequences of this upsurge in university enrolment has been a substantial increase in the supply of 
professionals, especially from programs that require low investment in infrastructure and equipment. In several areas this tendency has led to greater difficulties for graduates to secure employment in their academic training field. Furthermore, graduates entering the labor market find that their incomes do not meet the expectations they had at the onset of their studies (ESPINOZA; GONZÁLEZ, 2011, 2015; MELLER; LARA, 2010; URZÚA, 2012; TYMON, 2013).

The growing number of professionals and specialists entering the labor market has led to a mismatch between supply and demand of professionals, both in the public and private sectors (MELLER; LARA, 2010). Moreover, there is scarce information available on the aftermath and outcomes of higher education training, particularly relative to labor market demand, and this hinders students from making knowledgeable decisions when applying to post-secondary education after finishing high school. This lack of information also hinders the adoption of public policies that seek to improve employment conditions of future graduates, especially of those coming from low income groups. On the other hand, not only training results influence graduates' employability, but also students' gender and cultural background and their chances of accessing higher education in the first place (GRACIA, 2009; HARVEY, 2010; PAVLIN, 2010).

In this context of increasing competitiveness arose the concern over identifying the factors that facilitate or hinder graduates' labor market insertion. In Chile, in general, higher education outcomes have been approached from the perspective of employability statistics, and information about graduates' income levels has been added recently. Indeed, data concerning graduates' employability is provided by the Higher Education Information Service (Servicio de Información de la Educación Superior - SIES). That unit reports first and second year graduates' employment rates, as well as second and fifth year graduates' income levels (data in this last case comes from the state tax revenue service - Servicio de Impuestos Internos). ${ }^{2}$

Universities also conduct studies based on graduates' career monitoring, something which is required for their institutional accreditation process $^{3}$ (CENTRO INTERUNIVERSITARIO DE DESARROLLO, 2011). However, from an equity perspective, even the information on outcomes furnished by these institutions is limited and does not render account for the multiplicity of factors impinging on graduates' employability, such as social origin, degree of networking and cultural capital, among others. There are two possible explanations for why this happens: on the one hand, there is scarce 
conceptualization of the aspects of equity related to employment, and on the other hand, there is little disaggregated information available about this issue (ESPINOZA, 2007). Traditionally, universities have assumed that their role is only training students and that issues of labor insertion are not their concern, although in recent years this situation has begun to change.

Broadly speaking, the data suggests that the expansion of university education brought about significant upward social mobility until the first decade of the present century. Indeed, a return on the investment in a university degree is clearly perceived, regardless of the selectivity of theinstitution where the degree was obtained. Differences in incomes associated with the graduates' social background have also been noticed. However, with the increase in overall supply of professionals, the average incomes have fallen, causing social unease (SAPELLI, 2015). Hence, a latent possibility is that the differences in employment equity could be deeper or that they could deepen in the near future, affecting particularly those graduated in less selective institutions. Employment equity is understood as a situation in which graduates have equal access to the labor market regardless of their social background and the institution that trained them.

In recent years the issue has been thoroughly researched in Europe and North America which have higher education systems of large coverage (DE VRIES; NAVARRO, 2011; SALAS; MURILLO, 2012; PLANAS, 2013; EURIOPEAN COMMISSION, 2014; CAPELLII, 2015). Equity/inequity in graduates' employment access has been at the center of the discussion in European countries. In the literature about graduate employment, underemployment and unemployment, these issues are discussed in relation to differences in academic training, social class, gender, ethnicity and race (LAMO; MESSINA; WASMER, 2011; LIVANOS; NÚÑEZ, 2016). Brennan (2004), for example, tackled the issue pointing out that even although the studies showed that most higher education graduates in Europe had adequate employment, there were reasons to think that in the near future this situation could not be sustained, something that indeed happened. One of the factors behind the diagnosis is a mismatch between competencies obtained in higher education and the requirements of the productive sector (CARDOSO; FERREIRA, 2009; SCHOMBURG; TEICHLER, 2011; HAUSERMANN; KURER; SCHWANDER, 2015). This is explained, to a large extent, by an expanding credentialism in recent decades occurring in developed as well as in developing countries (MILLER; ROSENBAUM, 1997; 
BROWN, 2001; BOURDIEU; PASSERON, 2006; VAN DAMME, 2014; CHIROLEU; MARQUINA, 2017; THOLEN, 2017).

The transition from higher education systems to labor and the degree of job success are a test of graduates' competencies. Indeed, those who possess a degree and specific skills that correspond to employers' needs make the transition to the labor market without much difficulty or delay, which is considered an indicator of the relevance and quality of the training received (LINDBERG, 2008; HEYES, 2013). On the other hand, in countries that perform university rankings it has been observed that an institution's reputation has more influence on graduates' labor market insertion than the quality of the professional training (CIRIACI; MUSCIO, 2014; DRYDAKIS, 2016; LIVANOS; NÚÑEZ, 2016).

One aspect that has been less studied is the influence of the training process on labor market insertion (MELLER, 2010, 2011; TOMLINSON, 2008; TYMON, 2013). In studies conducted in Chile there has been a relative absence of research questions about graduates' perception of the impact of the training processes. Do they believe, for example, that the training process adds value to the return on their investment in a university education? How much does the level of selectivity of each university affect their income?

In this perspective, it is important to highlight the study by Urzúa (2012) who assessed economic returns on investment in higher education. He found evidence of the likelihood that obtaining a university degree in certain institutions might not be the best option from an investment-in-education viewpoint. Although the fundamental assumption behind the policy of higher education coverage expansion is that it fosters social mobility, bolsters job opportunities, reduces poverty and improves income distribution, Urzua's results do not favor these conclusions, particularly in the case of those who failed to complete their studies. According to his research, it is not obvious that access to higher education secures everyone future economic success, more so when there are signs that evidence failure in meeting expectations, low income, family indebtedness and oversupply (ESPINOZA; GONZÁLEZ, 2013). Urzúa (2012) finds it concerning that families consider it a fact of life that higher education guarantees a successful occupational future for their children. This would explain the increase in the number of young people entering higher education programs in any institution that offers them, and the oversupply of professionals in certain areas (social sciences, arts, humanities, among others). A study carried 
out in the Province of Concepción found that $78 \%$ of secondary students aspired to enroll in highly selective universities, which shows that they think that this type of institution maximizes their options for employment (GONZÁLEZ, 2014).

Reinforcing Urzúa's conclusions (2012), a study carried out by Améstica, Llinas-Audet and Sánchez (2014) founded that, in the period 2003-2009, increase in income levels for individuals with a higher education degree were $31.47 \%$ higher than the increase for those without tertiary education degrees. However, in the period 2006-2011 the rate of return on higher education was negative $(-15.47 \%)$, which showed that there was no improvement in income for people that studied during that period, so that it was unprofitable to study some of the programs offered by educational institutions.

With regards to social segmentation, a study undertaken with graduates of business administration in the Universidad de Chile, provides evidence that social class -understood as an expression of socioeconomic background- can be an important factor in determining returns on education in the labor market (NÚÑEZ; GUTIÉRREZ, 2004). The relation between social class background and returns on education in the labor market was statistically significant in different measurements. The order of magnitude of the gap between social class background and returns is nearly double, similar to the gender and race gaps informed by similar studies (GALARZA; YAMADA, 2013; HAMERMESH, 2011). The impact of social background on returns in the labor market is more important than academic performance which suggests that the degree of meritocracy in the labor market in Chile is low. In sum, the evidence pointed to the fact that academic performance does not necessarily have a direct relation with the quality of labor market insertion, which depends rather on a professional's social background.

In the case of teacher training in Chile, the effect of social segregation on academic performance has been analyzed on the basis of primary teacher education program students' social origin (PUGA; POLANCO; CORVALÁN, 2015). These authors concluded that education program students' social backgrounds influence educational performance in a relevant manner, leading to reinforcement of preexisting inequalities between students from different social origins. Education program students' social background is manifested in unequal initial training outcomes and segregated access to the labor market. Indeed, "primary school teachers of upper class background and those trained in more expensive and/or selective universities tend 
to teach more frequently in private schools while teachers of less privileged social backgrounds who were admitted to lower tuition, lower quality institutions (universities) tend to teach more frequently in public municipal schools" (PUGA; POLANCO; CORVALÁN, 2015: 86).

Schurch (2013) and Ramos et al. (2009), on the other hand, addressed the presence of variables at an aggregate level that would explain part of the differences in graduates' incomes in Chile. In both studies, researchers found important income differences depending on the type of degree obtained. Schurch found that the best paid degree (Medicine Program) earns average hourly incomes that triples the program with lower average salary (Primary Teacher Program), a finding consistent with the empirical evidence. Meller (2010) in turn calculated that traditional professions like medicine, civil engineering and economics rank in the top places of average hourly income, but concluded that studying in a university with low admission standards is, in any case, a profitable investment, although in smaller measure than studying in traditional universities. It happens, according to Meller (2010), because the market values the training and knowledge acquired in average by all professionals and careers in these universities.

The main findings in Schurch's work (2013) refer to the implications of some degrees' characteristics for first year graduates' incomes. He found that feminized professions -that is, those with a high percentage of women workers- and less selective programs (those with low entrance test scores) are negatively related to graduates' incomes, even after controlling for a set of individual characteristics like gender, social background and student performance, among others. Likewise, he identified an important consequence on income related to the formal length of the programs. Thus, the longer formal of a program `s lenght impacts income in a positive way, obtaining salaries 13\% higher for each additional semester, after controlling for individual and career-specific characteristics. In other words, the labor market gives greater value to longer programs (SCHURCH, 2013).

Leveling educational opportunities in terms of access can, however, increase the possibilities of social mobility, which manifests itself in the growing number of students whose parents did not access higher education (BREEN, 2010; ESPINOZA; GONZÁLEZ; URIBE, 2009; JENCKS, 1972; MARGINSON, 2016).

\section{THE PROBLEM}

There is no doubt that public policies encouraging an increase in access, coverage and retention in higher education, based on the 
assumption that it constitutes a factor that reinforces social mobility, have been successful. The sustained and rapid increase in the supply of professionals means growing competition in the labor market, and this in turn, makes it difficult to discern whether graduates from the social segments that have recently gained access to new higher education institutions have an equitable labor insertion process vis-àvis graduates from traditional institutions.

This study aims to to investigate the assessment of the labor insertion made by the graduates of the teaching program for elementary school at three Chilean universities with different levels of selectivity. For this purpose, we analyze the graduates' view of the training process and the influence on labor insertion they attribute the institution in which they obtained their degrees. The objective is to assess, from the graduates' standpoint, the impact of the education institution's selectivity on the quality of employment. Within this framework, the following research questions were put forth: How do primary teacher education program graduates assess the training they received? What degree of influence do graduates assign the educational institution over their labor insertion process? Are the training institution's selectivity levels relevant for the process of labor insertion?

In Chile, Primary Teacher Education Programs train teachers for the levels of compulsory education from the 1 st to the $6^{\text {th }}$ grades. In 2017, nationally, there were 157 programs ${ }^{4}$ which granted a degree in Primary Education (including various majors) in 53 postsecondary institutions (universities and professional institutes). The program is mainly offered by the new private universities (created after the reform of 1981), as shown in Table 1 . Around $43.8 \%$ of the offer was dictated in the evening. The expected programs `length goes between four and five years. ${ }^{5}$

TABLE 1. Number of teaching programs for elementary school provided in 2016 by type of institution

\begin{tabular}{|l|c|c|}
\hline \multicolumn{1}{|c|}{ Type of Institution } & Number of Programs & $\%$ \\
\hline Professional Institutes & 16 & $10,2 \%$ \\
\hline State Universities (CRUCH) & 29 & $18,4 \%$ \\
\hline Private Universities (CRUCH) & 13 & $8,3 \%$ \\
\hline New Private Universities & 99 & $63,1 \%$ \\
\hline Total & 157 & $100,0 \%$ \\
\hline
\end{tabular}

Source: SIES (2016). 
In 2016 there were 9,880 students enrolled in these programs at the national level, of which 1,996 were first-year students. It should be noted that in 2016 of the 157 programs with enrolled students, 86 $(54.8 \%)$ had no enrollment for the first year (SIES, 2016). This situation is explained by the entry into force of the teaching development law that, among other things, sets higher demands on PSU ${ }^{6}$ scores for the selection of applicants who intend to enter to teaching programs.

The institutions that participated in the study were classified into universities with high selectivity (HSU), medium selectivity (MSU) and low selectivity (LSU). The data available from official sources indicate differences in employment rates and income level of graduates when comparing programs and university selectivity level. Table 2 summarizes these contextual data, showing that the LSU has a lower employment rate for first year graduates and, noticeably, lower average income in comparison with the other universities.

TABLE 2. Income and employment for primary teacher education program graduates (2016)

\begin{tabular}{|c|c|c|c|}
\hline $\begin{array}{c}\text { University } \\
\text { according to } \\
\text { selectivity } \\
\text { level }\end{array}$ & $\begin{array}{c}\text { Average monthly income } \\
\text { (fourth- year graduates) } \\
\text { (US\$) }\end{array}$ & $\begin{array}{c}\text { Income range } \\
\text { according to university } \\
\text { (fourth-year graduates) } \\
\text { (US\$) }\end{array}$ & $\begin{array}{c}\text { Employment } \\
\text { (first-year } \\
\text { graduates) (\%) }\end{array}$ \\
\cline { 1 - 1 } HSU & \multirow{2}{*}{877} & $1021-1313$ & 96,6 \\
\cline { 1 - 1 } MSU & & $876-1020$ & 89,2 \\
\cline { 1 - 1 } LSU & & $730-876$ & 80,2 \\
\hline
\end{tabular}

Source: http://www.mifuturo.cl.

The initial hypothesis of the study argued that discourse of graduates from institutions with different levels of selectivity should recognize this situation and assess its impact on labor market access. Moreover, when explaining their own situation, graduates would probably relate it to the quality of their training and status of the institution where they graduated.

\section{METHODOLOGY}

This study is exploratory - descriptive in scope to the extent that it enquires into the individual interviewees' perception and general assessment of each dimension being analyzed (BOGDAN; 
TAYLOR, 1998; CANALES, 2014), something about which there is scarce research. The information and documentation that served as a basis was gathered from a set of twelve semi structured interviews conducted with graduates of primary teacher education programs of three universities situated in the Santiago Metropolitan Region: one highly selective (HSU), one moderately selective (MSU) and one with low selectivity (LSU). Interviews were applied between the months of December 2015 and March 2016.

The level of university selectivity included in the sample was determined on the basis of the years of institutional accreditation granted by the National Accreditation Commission of Accreditation (CAN) and the admission requirements defined by the institutions expressed in scores of the University Selection Test. The selection of programs was defined on the basis of the existing background regarding the supply of professionals in recent years and the growing number of graduates from this program in Chilean universities (ESPINOZA; GONZÁLEZ, 2011). Consequently, the selected institutions have the following features as indicated in Table 3.

TABLE 3. Average minimum admission score for primary teacher education programs and years of institutional accreditation

\begin{tabular}{|l|c|c|}
\hline \multicolumn{1}{|c|}{ University selectivity level } & $\begin{array}{c}\text { Average minimum } \\
\text { admission score 2011-2013 }\end{array}$ & $\begin{array}{c}\text { Years of institutional } \\
\text { accreditation }\end{array}$ \\
\hline High selectivity university (HSU) & 660 & 6 \\
\hline Intermediate selectivity university (ISU) & 476 & 3 \\
\hline Low selectivity university (LSU) & $<400$ & Not accredited \\
\hline
\end{tabular}

Source: SIES (2016).

The sample of interviewees was obtained from the graduate lists provided by the universities chosen for the study on the basis of two criteria: graduation year (2012 to 2014) and gender. The persons selected were contacted by phone or e-mail for afterwards conducting personal interviews. In this sense, it was a selective or subjective sample (purposive sample) (COHEN; MANION; MORRISON, 2007), which allowed obtaining relevant and valid background information on the program being studied.

A semi structured interview guide was used which included the most important areas of inquiry considered in the present study, 
that is: the graduates' assessment of the training they received at the university and.the process associated with the labor market access.

In order to safeguard the confidentiality of the information collected in the interviews, the perceptions and evaluations of the key informants are presented as follows: Before each testimony, the level of university selectivity (High, Medium or Low) was identified, the gender (Female $[\mathrm{F}]$ or Male $[\mathrm{M}]$ ), and the year of graduation (2012, 2013 or 2014) of the interviewee.

Discourse analysis considers the following dimensions and categories: admission into the program and university, assessment of program training (graduate profile, competencies acquired, pertinence of training for job performance) and labor insertion process. Processing of information was done using the Atlas Ti Program.

\section{RESULTS}

Below are exposed and interpreted the opinions of the graduates of three teaching programs for elementary school at universities with different levels of selectivity. The information provided by the interviewees has been organized according to:

1. Background elements: Family environment and determinants of admission into the program and university.

2. University training: graduate profile, relevance and sufficiency of competences acquired in the training process.

3. Pertinence of program training for job performance.

4. Labor market access.

\section{PROGRAM ADMISSION}

Regarding educational trajectories prior to get access into university training, those who graduated from universities of high and intermediate selectivity reported having an initial interest in teacher education, as outlined below:

From school I was always interested in teaching. That's why I graduated from the Teaching Programs for Elementary School, although previously I had studied a Bachelor in Chemistry. But I switched, I wanted something humanistic and the only program that allowed me to choose something with scientific orientations was a Teaching Program for Elementary School (HSU - M - 2014).

I studied History Teaching Program for a year and a half (three semesters). I did not like the program, and then, within the same university, I switched to the Teaching Program for Elementary School (MSU - H - 2014). 
By contrast, in the case of graduates from the low selectivity university, they suggested that their inclination for the program was the result of an exploration of alternatives and of moving along in the definition of a specific disciplinary area. The following testimonies account for the aforementioned:

In school I wanted to study something that has nothing to do [with teacher education], so I entered business administration. Although it was unrelated, I think that it was useful nonetheless because when I finished school I didn't know what to study (LSU - M - 2014).

It is interesting to note that in the case of graduates from the three types of universities, enrollment into Teaching Programs for Elementary School occurred after opting for other training alternatives after graduation from higher education. In other words, to study a teaching program for elementary school constituted a second option, which probably would be explained by the low assessment given to the teaching profession in Chile. This is illustrated by the following statement:

(...) In high school I was never too inclined towards humanistic studies, I leaned rather to mathematics. However, after finishing high school I studied a Teaching History Program for two years, and then I decided to switch to the [primary] teacher education program in the same university (LSU - M - 2014).

Complementing the above, González (2014) has concluded that secondary students' aspirations are strongly disposed toward selective universities. These aspirations are correlated with family cultural capital, the type of school attended and the student's educational performance, to which must be added other non-school paths of inequality creation, like attending pre-university school.

Interviewees' family contexts stand out for the high expectations placed on university training and future employment, which is consistent with the point of view that attributes higher education a significant impact on social mobility. In the words of graduates from both low and intermediate selectivity university there is an evident appreciation of becoming the first professional in the family. This achievement, in turn, encourages other family members to undertake or resume studies, which attests to the importance placed by the family on counting with this first university graduate, as is expressed in the following statements:

My Old Man [my Father] completed secondary school and my Old Lady [my Mother] finished Ninth Grade. My sister has done technical nursing studies. So the first university graduate was me (MSU - M - 2014). 
I am the first professional in my family. My Mother completed primary school [ $8^{\text {th }}$ Grade]. My Father completed secondary school. I have an elder sister that completed secondary education in a two-years-in-one program. With my higher education training I kind of motivated her so she decided to finish her secondary school. And my younger sister too, she only attended primary school and now she's also studying a two-years-in-one program (LSU - M - 2014)

In interviewees from MSU and LSU, the low levels of both objectified and institutionalized cultural capital stand out. This results from the process of massification of higher education in Chile that started in 1981 and has intensified significantly during the last decade. This massification was due to the increased access to numerous institutions of dubious quality by those segments of students with the lowest admission test scores, coming from low income families.

When analyzing immediate factors that prompted the choice of university degree program, graduates from the low selectivity university state that they were influenced by persons who they trusted, and view these persons as guiding references in a moment of confusion. One of these graduates points out:

Because my Mother was a teacher, she always told me how nice it is to work among children. I started to find it engaging how a teacher performs in class and how [being a teacher] you could also learn to perform by teaching. So, my Mother as a model who was close to me made me feel the program as something close and familiar (LSU - F - 2014).

It is surprising that the Mother, as a role model, was a teacher. We can appreciate here what Puga, Corvalán and Polanco (2015) describe as reproduction of training segregation, acknowledging students' social origins. By comparison, graduates from the high selectivity university point to academic and vocational factors as among the main ones that led them to enter the program, like the following testimony shows:

I studied chemistry but I wanted to switch and study a humanist program so I entered a pre-university level course in history to prepare for the university entrance test. I took the test but then changed my mind and wanted a scientific program. The only scientific program I could enter having taken the history entrance test was the primary teacher education program, in which you can choose a science major, regardless of whether you entered through the history or the science test (HSU - M - 2012).

\section{UNIVERSITY ENTRANCE}

Besides the program choice, we inquired about university selection. We found that the reasons and motivations that led the students 
to choose a high or mid-low selectivity university were not its training quality, which was probably taken for granted, nor the employability it assured, but rather what they thought were the university's strategic guidelines or certain added value which characterized the chosen institution. This is exemplified by the following answer:

The university's teacher education training program has a well-earned prestige, but back when I was choosing I didn't know this. Besides, people talked about HSU1, but there was also HSU2, HSU3, etc. That's why when I talked to people who were studying at the university it was clear to me that this was what I was looking for, even talking with people in other programs who pointed out the difference between the $\mathrm{U}$ and other universities (HSU - M - 2012).

It is interesting that the same point of view can be found among the MSU interviewees, who identify an institutional profile related to the educational project. Graduates show a defensive attitude towards disapproval for studying in a not socially accepted university, justifying their choice with non-academic arguments, or by making it clear that, whatever the case, they could have entered other institutions if they had so wanted. An example follows:

When I entered university I could have chosen any university, but my option relates to how this university thinks, to its orientation towards what one does in life and how one thinks. In this sense, more than so much marketing, the important thing was centering on what one believes (MSU - F - 2013).

On the other hand, graduates from the low selectivity university express personal and practical reasons and arguments. That is, the motives for entering this university are not related to the institution's identity or the quality of its training. The testimonies lead us to conclude that the reasons that guide university selection refer to situations external to the students, mostly economic ones, as is shown in the following lines:

I entered this university because it was cheaper. In school I had a scholarship and other financial aid, and I could have entered other universities in which I would have had to make co-payments, so they were more expensive. So that's mainly why I made the decision ... (LSU - M - 2014).

\section{ASSESSMENT OF UNIVERSITY TRAINING}

Assessment of training received by primary teacher education program graduates was examined in the interviews referring to three issues: a) identifiable aspects of graduate profile and their impact on employment; b) assessment of the competences acquired in the training process; and c) pertinence of program training for job performance. 


\section{a) Graduate profile}

Knowledge about primary teacher education program graduate profile does not differ importantly among graduates from high, midlow and low selectivity universities. Indeed, interviewees in general point out unawareness of and unfamiliarity with the notion. In this context, graduates from the high selectivity university, although declaring not to have much knowledge about graduate profile, see an association between the program's graduate profile and the "sense of social responsibility" of the university. A statement making this point follows:

Truth is that for me the program's graduate profile was not at all clear. What we did know was that in the university they gave much importance to the sense of social responsibility, and this was evident through the training process (HSU $-\mathrm{M}-2013$ ).

In contrast to this, graduates from the intermediate and low selectivity universities explain that, although they were told about the graduate profile or read about it, it was not very clear or they don't remember if specific competencies were included as part of this profile. They view graduate profile as a secondary aspect that the university discloses at occasions before students enter the program or on entrance, but only in a declarative and circumstantial manner. During the course of the program students don't reflect on the implications of graduate profile on labor insertion and job performance. Referring to this, interviewees said:

Truth said, I can't remember about graduate profile. But I can tell you that at the beginning of the program students get to know everything about graduate profile and all they need to know about the program (MSU - M - 2014).

To let us know about student profile they handed us out brochures [on entering the program] and they gave us a leaflet detailing a student's characteristics. Maybe there was insufficient discussion or an instance of conversation where we could talk about it in more detail, but we were provided the information (LSU - F - 2014).

It surprises us that institutions don't supervise on a regular basis the degree of fulfillment of graduate profile and that they don't report students about it. Probably, this is because the teachinglearning process is not centered on graduate profile.

\section{b) Assessment of the training process}

About the training process in the universities researched in this study, interviewees spontaneously mention the high appraisement they hold for the theoretical training received. Indeed, from the graduates' words - out of all three types of universities: high, mid- 
low and low selectivity - we discern a general pattern of satisfaction with contents in the study plan.

Inquiring further, graduates from the three universities expressed dissatisfaction with shortcomings in professional performance training. They pointed to shortcomings in child handling in the classroom, use of teacher-administrative tools and didactic skills upon graduation from the program. This would express a decoupling between the training received by students and real-teaching at schools. The following statements refer to this:

I think that I graduated knowing a lot about learning theories and teaching, but I realized that I lacked technical skills. I didn't know how to use the class book, how to teach, how to conduct an interview with a student's parents (HSU $-\mathrm{M}-2013$ ).

I feel that some subject matters were too superficial, that they lacked depth, didactic transposition for example, and that contents are carried out in practice with children. The program is undemanding in those practical matters (HSU $\mathrm{M}-2012)$.

They should teach you how to fill out the class book because every teacher has to do it. I had a trainee and I cared a lot about how to write in the class book because in university they don't teach you how to do it (MSU - M - 2014).

Interviewees from the LSU have a quite radical view about gaps in training, as is expressed in the following opinion:

Training was $\mathrm{OK}$ and the only shortcoming was in contents. I mean practical knowhow. Clearly, one has to educate oneself, but there are things that I sometimes ask myself why they didn't teach them to me and why is it that I had to learn them on my own, on the way (LSU - M - 2014).

These cases show that teacher education programs are outdated or not connected to everyday teacher labor, and that they focus training solely on a theoretical point of view.

\section{c) Pertinence of program training for job performance}

Another issue addressed in this study is primary teacher education program graduates' understanding of the training received and its pertinence for job performance. In this sense, the three groups of interviewees point out being satisfied with their career paths. However, when asked about pertinence of program training for job performance, their answers are emphatically negative.

Opinions gathered in the interviews show dissatisfaction with taught knowledge about teacher's daily work- This tarnishes perception of the overall training received. This kind of criticism 
presents itself in all three kinds of interviewees' opinions. Some enlightening words follow:

In school you look at many angles. We had a course (in the program) about "Problem settlement", but we were never taught to deal with, for example, parent/guardian disagreement, or to deal with students' personal issues. Educational contents were too theoretical and not at all practical. We didn't have any connection with reality (HSU - M - 2012).

Because there are universities that teach you to perform only in particular schools and we've talked about it with our peers. Nevertheless, I was educated [in the program] for the real world, for public [municipal] schools where you find children with all kinds of problems, not only children that know how to deal with the world. For example, I started at school and didn't know how to write in the class book, I remember that I was about a month asking how do I do this and how do I do that. So this was lacking in training: the class book. I don't think that it's too expensive to buy a book so all students can get acquainted with it while training. Another thing that [the program] lacks is linkage with special education because there are a lot of situations that need it. Special education teachers go their way and we go ours (MSU - F - 2013).

We dealt with that in class, but then clashed with it in school practice because schools are behavior pedagogy oriented, they are not constructivist. So we clashed with that because we were taught something different in university. So it went like: "Ok, so here they teach me this but in a real school I can't do things like I've been taught in university". Get it? [Do you understand?] So that was the limit there was in university (LSU - F - 2014).

So you reflected on things you did wrong or that you were wrong about. For example, dealing with children with special needs. For me that was not akin (LSU - F - 2014).

So, as can be appreciated, for teachers that graduated from high, mid-low and low selectivity universities training flaws are associated with a lack of consistency between what they were taught at the university and pedagogical practices they encountered in schools. Criticism points out the following issues: dichotomy between pedagogical constructivism learned in Teacher Education Programs and behaviorism that is practiced in schools; inadequate training on dealing with children with special needs; conflict settlement; links with special need children teachers; and lack of technical knowledge going into the labor market that can be appreciated in, for example, a lack of skills in the use of basic teacher management resources, like teacher class books.

\section{LABOR INSERTION PROCESS}

Primary teacher education program graduates' labor insertion is a key aspect for understanding the way they perceive their training program. 
A fast and easy entrance into the job market favors a good perception of university training. On the other hand, difficulties or impossibility in entering the labor market is a cause of disappointment with the educational career followed and in particular with the university training.

Graduates' perception show, in general, a sense of satisfaction with the transit from university to labor. They also show how important the time interval between graduation and job placement is for graduates. The time frame between graduating and obtaining a first professional employment is crucial for graduates' assessment of the training they received. This is shown in the following paragraphs:

Yes, I found work right away. I graduated [from the program] in December and in January I had found a job. During the first year I worked in a school in Cerrillos. But I left that job and almost right away, in two weeks, I found another in a chartered school in Santiago where I worked for two years. That was until last year. I've worked as a teacher for three years. Now I've found a new job, in Maipú. I start working next week (HSU - M - 2012).

I had just graduated when I found a job so it wasn't difficult for me. I did my practicum in a private school and now I'm working in a public (municipal) school in La Reina. So I don't complain, I found a job really fast. I have done well as far as work is concerned (MSU - F - 2013).

I started working when I was finishing studying. I worked in a school for two consecutive years in a SIMCE [Sistema de Medición de la Calidad de la Educación] workshop. In last year of school they even wanted to enableme to work as head teacher (LSU - M - 2014).

\section{CONCLUSIONS}

The evidence collected does not warrant sufficient proof to sustain the hypothesis that guided this study. Graduates don't recognize a link between academic training and labor market access. They are rather critical of academic training so we can conclude that they attribute labor insertion to personal traits. University prestige in labor insertion is perceived as an implicit positive influence (HSU), and for interviewees from MSU and LSU at least a non-negative influence.

From a standpoint of equity in labor insertion selectivity level of the higher education institution where the degree is obtained doesn't seem relevant. Indeed, according to graduates' perception no differences were found about labor insertion among HSU, MISU and LSU graduates. Labor market access is quick and "trauma" free according to graduates from all three types of universities, even although Ministry of Education data shows differences in employability and 
income. It is a possible unconscious adjustment between expectations and self-assertion, evidence of which is students' declaration that entering an MSU or a LSU was a choice and that selecting a primary teacher education program was an election between others.

Graduates understand that their successful labor insertion is due to training received. Primary teacher education program graduates understand graduate profile as meaning professional profile. There is no positive assessment of self-learning processes or they have not been sufficiently taught at university that reveals a shortcoming in program training. This perception is reinforced by the fact that graduates don't remember the relevant aspects of the training process, except those coming from high selectivity universities, which highlights the instrumental character of university training, focused solely on specific technical and professional competences.

\section{REFERENCES}

ACCIÓNEDUCAR. Gratuidad Universal en Educación Superior y su Impacto en la Cobertura. Serie Análisis AcciónEducar, Santiago, n. 33, 2015. Disponible en: <http:// accioneducar.cl/wp-content/files_mf/1438201882Analisisgratuidadycobertura.pdf>. Consultado el: 12 dic. 2016.

AMÉSTICA, L.; LLINÁS-AUDET, X.; SÁNCHEZ, I. Retorno de la educación superior en Chile. Efecto en la movilidad social a través del estimador de diferencias en diferencias, Formación Universitaria, La Serena, v.7, n. 3, p.23-32, 2014.

BOGDAN, R.; TAYLOR, S. Introduction to Qualitative Research Methods. Nueva York: John Wiley \& Sons, Inc., 1998.

BOURDIEU, P.; PASSERON, J.C. Los herederos. Los estudiantes y la cultura. Buenos Aires: Siglo Veintiuno Editores, 2006.

BREEN, R. Educational expansion and social mobility in the 20th century. Social Forces, v. 89 , n. 2, p. 365-388, 2010.

BRENNAN, J. Graduate Employment: Issues for Debate and Inquiry. International Higher Education, Boston, n. 34, p.12-14, 2004.

BROWN, D. The social sources of educational credentialism: Status cultures, labor markets, and organizations. Sociology of Education, Washington, D.C., v.74, extra issue, p. 19-34, 2001.

BRUNNER, J.J. Educación Superior en Chile. Santiago: Ediciones Universidad Diego Portales, 2009.

BRUNNER, J.J.; URIBE, D. Mercados universitarios: el nuevo escenario de la educación superior. Santiago: Ediciones Universidad Diego Portales, 2007. 
CANALES, M. Escucha de la Escucha. Análisis e Interpretación en la Investigación Cualitativa. Santiago: LOM Ediciones, 2014.

CAPELLI, P. Skills gaps, skills shortages, and skills mismatches: evidence and arguments for the United States. Industrial and Labour Relations Review, Itaca, v. 68, n. 2, p. 251-290, 2015.

CARDOSO, A.; FERREIRA, P. The dynamics of job creation and destruction for university graduates: why a rising unemployment rate can be misleading. Applied Economics, London, v. 41, n. 19, p. 2513-2521, 2009.

CARRASCO, E.; ZÚÑIGA, C.; ESPINOZA, J. Elección de carrera en estudiantes de nivel socioeconómico bajo de universidades chilenas altamente selectivas. Calidad en la Educación, Santiago. n. 40, p. 96-128, 2014.

CENTRO INTERUNIVERSITARIO DE DESARROLLO - CINDA. Educación Superior en Iberoamérica. Informe 2011. Santiago: CINDA-Universia, 2011.

CIRIACI, D.; MUSCIO, A. University Choice, Research Quality and Graduates' Employability: evidence from Italian national survey data. European Educational Research Journal, v.13, n. 2, p. 199-219, 2014.

COHEN, L.; MANION, L.; MORRISON, K. Research Methods in Education. Oxford: Taylor \& Francis, 2007.

COMISION NACIONALDE ACREDITACIÓN. Manual de Autoevaluación Interna para Universidades. Santiago: Comisión Nacional de Acreditación, 2014.

CHIROLEU, A.; MARQUINA, M. Democratisation or credentialism? Public policies of expansion of higher education in Latin America. Policy Reviews in Higher Education, London, v. 2, n.1, p.139-160, 2017.

DE VRIES, W.; NAVARRO, Y. ¿Profesionistas del futuro o futuros taxistas? Los egresados universitarios y el mercado laboral en México. Revista Iberoamericana de Educación Superior, Ciudad de México, v. 2, n. 4, p. 3-27, 2011.

DRYDAKIS, N. The Effect of University Attended on Graduates' Labour Market Prospects: A Field Study of Great Britain. IZA Discussion Paper $\mathbf{n}^{\mathbf{0}}$ 9826, Bonn, 2016. Disponible en: < http://ftp.iza.org/dp9826.pdf>. Consultado el: 10 sept. 2017.

ESPINOZA, O. Solving the Equity/Equality Conceptual Dilemma: A New Model for Analysis of the Educational Process. Educational Research, London, v. 49, n. 4, p. 343-363, 2007.

ESPINOZA, O. Creating (in) equalities in access to higher education in the context of structural adjustment and post-adjustment policies: The case of Chile. Higher Education, Netherlands, vol. 55, n. 3, p. 269-284, 2008.

ESPINOZA, O. (ed.). Equidad e Inclusividad en la Educación Superior en los Países Andinos: Los Casos de Bolivia, Chile, Colombia y Perú. Santiago: Ediciones Ucinf, 2013.

ESPINOZA, O.; GONZÁLEZ, L. Perfil socioeconómico del estudiantado que accede a la educación superior en Chile (1990-2003). Estudios Pedagógicos, Valdivia, v. 33, n. 2, p. 45-57, 2007. 
ESPINOZA, O.; GONZÁLEZ, L. La Crisis del Sistema de Educación Superior Chileno y el Ocaso del Modelo Neoliberal. In: BARÓMETRO DE POLÍTICA Y EQUIDAD, Nuevos actores, nuevas banderas. Santiago: Fundación Equitas - Fundación Friedrich Ebert, p. 94-133, 2011. Disponible en: <http://www.fundacionequitas.org/descargas/barometro/ barometro03.pdf>. Consultado el: 12 dic. 2016.

ESPINOZA, O.; GONZÁLEZ L. Promesas Incumplidas en Educación Superior Bajo el Gobierno de Piñera. In: BARÓMETRO DE POLÍTICA Y EQUIDAD, Cae el Telón. El Ultimo Año del Gobierno de Sebastián Piñera. Santiago: Fundación Equitas-Fundación Friedrich Ebert, p.112-131, 2013.

ESPINOZA, O.; GONZÁLEZ, L. (2015) Equidad en el Sistema de Educación Superior en Chile: Acceso, Permanencia, Desempeño y Resultados. In BERNASCONI, A. (ed.). Educación Superior en Chile: Transformación, Desarrollo y Crisis. Santiago: Ediciones de la Universidad Católica de Chile, p. 517-579, 2015.

ESPINOZA, O.; GONZÁLEZ, L.; URIBE, D. Movilidad Social en Chile: El Caso del Gran Santiago Urbano. Revista de Ciencias Sociales, Maracaibo, v. XV, n. 4, p. 586-606, 2009.

EUROPEAN COMMISSION. Employment and Social Developments in Europe 2014. Luxembourg: Publications Office of the European Union, 2014.

HARVEY, L. New realities: The relationship between higher education and employment. Tertiary Education and Management, London, v. 6, n. 1, p. 3-17, 2010.

GALARZA, F.; YAMADA, G. Labor Market Discrimination in Lima, Peru: Evidence from a Field Experiment. Documento de Trabajo, n. 12-3, Perú: CIUP, 2012.

GALLEGUILlOS, P.; HERNÁNCEZ, T.; SEPÚLVEDA, F.; VALDÉS, R. Reforma a la Educación Superior: Financiamiento Actual y Proyecciones. Santiago: Ministerio de Hacienda del Estado de Chile, 2016.

GONZÁLEZ, A. Aspirar a una Universidad Selectiva y Concretar las Aspiraciones: Factores Determinantes. Calidad en la Educación, Santiago, n. 40, p. 235-267, 2014.

GRACIA, L. Employability and Higher Education: Contextualising Female Students' Workplace Experiences to Enhance Understanding of Employability Development. Journal of Education and Work, London, v. 22, n. 4, p. 301-318, 2009.

HAmermesh, D. Beauty Pays. Why Attractive People Are More Successful. New Jersey: Princeton University, 2011.

HAUSERMANN, S.; KURER, T.; SCHWANDER, H. High-skilled outsiders? Labour market vulnerability, education and welfare state preferences. Socio-Economic Review, Oxford, v.13, n. 1, p. 235-258, 2015.

HEYES, J. Vocational training, employability and the post-2008 jobs crisis: Responses in the European Union. Economic and Industrial Democracy, Uppsala, v. 34, p. 291-311, 2013.

JENCKS, C. Inequality: A Reassessment of the Effect of Family and Schooling in America. New York: Basic Books, 1972. 
LAMO, A.; MESSINA, J.; WASMER, E. Are specific skills an obstacle to labour market adjustment? Labour Economics, Maastricht, v.18, n. 2, p. 240-256, 2011.

LATORRE, C.; GONZÁLEZ, L.; ESPINOZA, O. Equidad en Educación Superior: Evaluación de las Políticas Públicas de la Concertación. Santiago: Editorial Catalonia/ Fundación Equitas, 2009.

LEYTON, D.; VÁSQUEZ, A.; FUENZALIDA, V. La experiencia de estudiantes de contextos vulnerables en diferentes Intituciones de Educación Superior Universitaria (IESU): Resultados de investigación. Calidad en la Educación, Santiago, n. 37, p. 61-97, 2012.

LINDBERG, M. Diverse routes from school, via higher education, to employ-ment: A comparison of nine European countries. Turku: UNIPRINT, 2008.

LIVANOS, I.; NÚÑEZ, I. Better safe than sorry? The role of stratification and quality of higher education in the labour market outcomes of graduates across Europe. Economic and Industrial Democracy, Uppsala, v.37, n. 2, p. 345-372, 2016.

MARGINSON, S. The worldwide trend to high participation higher education: dynamics of social stratification in inclusive systems. Higher Education, Amsterdam, v. 72, n. 4, p. 413-434, 2016.

MELLER, P. Rol de la universidad en la determinación del ingreso de los profesionales. In: MELLER, P. (ed.). Carreras universitarias: rentabilidad, selectividad y discriminación. Santiago: Uqbar Editores, p.103-126, 2010.

MELLER, P. Universitarios, ¡el problema no es el lucro, es el mercado!. Santiago: CIEPLAN - Uqbar, 2011.

MELLER, P.; Lara, B. Carreras universitarias: Rentabilidad, Selectividad y Discriminación. Santiago: Editorial Uqbar, 2010.

MIFUTURO.CL. Mi Futuro. Santiago: Ministerio de Educación, 2010. Disponible en: <http://www.mifuturo.cl>. Consultado el: 23 nov. 2016.

MILLER, S.; ROSENBAUM, J. Hiring in a Hobbesian World: Social infrastructure and employers' use of information. Work and Occupations, v. 24, n. 4, p. 498-523, 1997.

NÚÑEZ, J.; GUTIÉRREZ, R. Class Discrimination and Meritocracy in the Labor Market: Evidence from Chile. Estudios de Economía, Santiago, v. 31, n. 2, p.113-132, 2004.

Organización para la Cooperación y el Desarrollo Económicos - OCDE.El aseguramiento de la calidad en la educación superior en Chile. Paris: OCDE, 2013.

PAVLIN, S. Higher Education and Employability Issues. DECOWE Working Papers Series, December. Department of Competencies in the World of Work and Education, 2010. Disponible en: <http://www.decowe.org/static/uploaded/htmlarea/test/ DECOWEWorkingpaper_201012Pavlin.pdf>. Consultado el: 10 nov. 2016.

PLANAS, J. Los itinerarios laborales de los universitarios y la calidad de su inserción profesional. Revista de la Educación Superior, Ciudad de México, v. 42, n. 165, p. 31-62, 2013. 
PUGA, I.; POLANCO, D.; CORVALÁN, D. Segregación de la formación y carrera docente y su rol en la reproducción social de la desigualdad. Calidad en la Educación, Santiago, n. 43, p.57-102, 2015.

RAMOS, J.; COBLE, D.; ELFERMAN, R.; SOTO, C. Determinantes de los salarios por carrera. Documento de Trabajo, nº. 300. Santiago: Departamento de Economía, Universidad de Chile, 2009. Disponible en: <http://repositorio.uchile.cl/bitstream/handle/2250/144054/ Determinantes-de.pdf? sequence $=1$ \&isAllowed $=\mathrm{y}>$ Consultado el: 15 feb. 2017 .

SALAS, I.; MURILLO, F. Los profesionistas universitarios y el mercado laboral en México: convergencias y asimetrías. Revista de la Educación Superior, Ciudad de México, v. 42, n. 165 , p. $63-81,2012$.

SAPELLI, C. Chile: ¿̇más equitativo? Una mirada a la dinámica social del Chile de ayer, hoy y mañana. Santiago: Ediciones UC, 2015.

SCHOMBURG, H.; TEICHLER, U. Employability and Mability of Bacelor Graduates in Europe. New York: Springer, 2011.

SCHURCH R. El retorno de las carreras: Un estudio de caso de los factores que inciden en las remuneraciones de universitarios recién titulados. Calidad en la Educación, Santiago, n. 38 , p. 215-244, 2013.

SISTEMA DE INFORMACIÓN DE LA EDUCACIÓN SUPERIOR - SIES. Servicio de Información de Educación Superior. Santiago: Ministerio de Educación, 2017. Disponible en: <http://www.mifuturo.cl/index.php/servicio-de-informacion-de-educacion-superior/ quie>. Consultado el: 20 abr. 2017.

THOLEN, G. Graduate Work: Skills, Credentials, Careers, and Labour Markets. Oxford: Oxford University Press, 2017.

TOMLINSON, M. The degree is not enough': students' perceptions of the role of higher education credentials for graduate work and employability. British Journal of Sociology of Education, London, v. 29, n. 1, p. 49-61, 2008.

TYMON, A. The student perspective on employability. Studies in Higher Education, London, v. 38, n. 6, p. 841-856, 2013.

URZÚA, S. La Rentabilidad de la Educación Superior en Chile. Revisión de las Bases de 30 años de Políticas Públicas. Estudios Públicos, Santiago, n. 125, p.1-52, 2012.

VAN DAMME, D. How Closely is the Distribution of Skills Related to Countries' Overall Level of Social Inequality and Economic Prosperity? OECD Working Papers n.105. OECD Publishing: Paris, 2014.

\section{NOTES}

${ }^{1}$ Los autores agradecen el financiamiento otorgado por el Proyecto Fondecyt No 1151016 titulado "Equidad en la Educación Superior en Chile: Resultados de la Formación Universitaria en la Inserción Profesional y Laboral de los Egresados".

${ }^{2}$ Data can be checked at: http://www.mifuturo.cl 
${ }^{3}$ Institutional accreditation: Quality certification granted in Chile by the National Accreditation Commission to higher education institutions. It is measured in years of accreditation from 1 to 7 years.

${ }^{4}$ Including special graduation programs.

${ }^{5}$ In Chile, higher education institutions determine the length of programs, starting from a minimum of eight semesters. For market reasons, some institutions offer programs with the minimum lenght.

${ }^{6}$ PSU: University Admission Test that most Chilean universities use to select applicants. It is applied once a year.

Submission: $07 / 12 / 2017$

Approbation: 18/04/2018

Contact:

Oscar Espinoza

Center of Advanced Studies, Universidad de Playa Ancha Traslaviña 450, Viña del Mar, Chile

Postal Code: 2581782 